\title{
From symbolic reforms to radical politics through crisis
}

\author{
Nicole Fabricant
}

Published online: 25 August 2011

(C) Springer Science+Business Media B.V. 2011

Evo Morales-elected as the first indigenous President in the history of the Americas, in December 2005-rode the wave of social movement protests and victories from 1999 to 2004, and had taken to the streets to stand against a neoliberal model of economic reform, redistribute critical resource wealth, and create a constituent assembly to rewrite the constitution. One of Morales's many preelectoral promises to social movements was a new agrarian reform law that implemented a radical redistribution of land in the East, and the elimination of the latifundio, or unproductive landowner.

Morales announced his new plans for agrarian reform ${ }^{1}$ a year and half into his first term as President, in August 2006, at the historic and symbolic site of Ucureña, a small, dusty village on the high plains near Cochabamba. Five decades earlier, President Victor Paz Estensorro had gone to Ucureña to sign the 1954 Agrarian Reform Act, ${ }^{2}$ in an attempt to radically redistribute lands to indigenous peoples as part of a broader national agenda. Although the original Agrarian Reform Act achieved its objective of land redistribution in the West, it did not solve the problems in the East, where a series of military dictatorships characterized by

\footnotetext{
1 This law was called the Communitarian Redirection Law, which included four critical pillars that distinguished it from its predecessor. One, social and economic function: all land that does not fulfill a social and economic function-that is, as speculative or unproductive large-scale holdings-is subject to expropriation by the state and redistribution to peasants. Two, mechanization: tractors and other equipments will be provided to small-scale farmers. Three, credit: an Agricultural and Rural Development Bank will lower interest rates for small-scale producers (from 20 to 6\%). Four, eco-markets: the state will support development of foreign markets for ecological products (organics and so forth) and develop options for long-term sustainability.

2 The National Revolution in Bolivia sought to introduce universal suffrage, carried out a sweeping land reform, promoted rural education, nationalized the country's tin mines, and incorporated Aymara and Quechua peasants into the nation-state.
}

N. Fabricant $(\bowtie)$

Towson University, Towson, MD, USA

e-mail: nfabricant@towson.edu 
favoritism and political patronage exacerbated the problem of unequal land ownership. ${ }^{3}$ Consequently, a second agrarian reform, called the National Institute for Agrarian Reform Law of 1996, attempted to correct the shortcomings of the 1954 agrarian reform law by distributing land more equitably and rationalizing land markets and property titles in the East. ${ }^{4}$ With only a few notable exceptions of progress in titling for Lands of Common Origin (Tierras Comunitarias de Origen or Indigenous Territories-TCO) in the East, however, the 1996 law did not respond to the increasing demand for the allocation of lands to campesinos and settlers.

This landed inequality remains deeply etched in the geographical and political landscape of Eastern Bolivia, where approximately one hundred and fifty families own almost all of the productive land. This concentration of landholding is especially acute in departments like Santa Cruz, the agro-industrial capital of Bolivia and center of political resistance to the Morales administration. Importantly, these latifundios control regional politics and have been calling for a form of decentralized autonomy, which would increase their control over natural resource wealth in the region. ${ }^{5}$ Movements in Santa Cruz, like the Landless Peasant Movement or MST-Bolivia's ${ }^{6}$ national agenda of radical land redistribution has created a political backlash, among elites who rely upon speculative and unproductive landholding as insurance against cyclical downturns (Gustafson 2006). Critically, these trends have heighted this landed oligarchy's opposition to both redistributive land reform and nationalist policies for establishing sovereignty over natural resource exploitation. And so, when Morales announced his plans for Agrarian Reform on that cool day in August at Ucureña, regional elites began organizing spectacular displays of resistance, from hunger strikes in central plazas to road blockades and protest marches. Elites in Santa Cruz mobilized symbols of their historic rights to land and productive resources in their region. Youth wore t-shirts reading, "Esta tierra es mia carajo" [This land is mine, goddamn it!].

Simultaneously, indigenous agrarian movements were also orchestrating symbolic and spectacular shows of land and resource reclamation. On the morning of his signing, Morales drove into town on a Chinese tractor bedecked with MAS (Movement Toward Socialism) flags and covered in confetti. Behind him followed a convoy of tractors manufactured in a joint venture between Venezuela and Iran and sold to Bolivia by Venezuelan President Hugo Chavez. The government announced its plans to distribute as many as 500 tractors - made in Venezuela, Iran, Spain, and China-as well as 2,000 individual land titles. These dueling symbolic shows

\footnotetext{
3 Lesley Gill (1987) notes that under dictatorship of Hugo Banzer, lowland producers and large-scale commercial agriculture received unequivocal support. They also received large extensions of land from Banzer in exchange for support of his military regime of governance.

${ }^{4}$ Benjamin Kohl (2003) points out that this neoliberal land legislation symbolically gave rights to indigenous communities, but failed to follow through on its promises.

5 While Morales was vehemently opposed to regional forms of autonomy in the new constitution, he actually surrendered to such powerful groups by including in Article 6-8 in the constitution, which gave exclusive rights to departments for control over natural resource policy, land reform, and taxation.

6 MST-Bolivia borrows its name from the famous Brazilian Workers' Movement. They occupy latifundio land, squat on the land, and farm in collective and cooperative ways in order to call for a radical agrarian reform from below.
} 
eventually receded as elites realized that the new legislation would not disrupt their dependence on export-oriented industries like soy, nor would it attempt to expropriate the land they had illegally acquired.

It is clear, in the case of Bolivia, that the indigenous agrarian movements gathered that day in Ucureña supported Morales, who they often described as "one of us," a coca-grower and union organizer, who came out of the battles to reclaim natural resources. For after all, many of these agrarian movements brought Morales to power and deeply identified his pre-electoral campaign and his attempt to create a more progressive and inclusive state. As movement organizers from the MSTBolivia stated, "We are now a part of this state." Yet, Morales's promise for radical agrarian reform has been compromised by the globalization of food production, the worldwide demand for export-oriented crops like soy, which continue to create a highly uneven distribution of resources and land. The global and international demand for soy, in part, a response to the energy crisis, has fueled increased deforestation and production of Bolivian soy. The high global prices of crude oil and excessive use of fossil fuels by industrialized nations have led to a more urgent and aggressive search for turning food crops into new energy resources in peripheral areas of South America. The promotion of a biodiesel market has also been accompanied by further consolidation of unequal landownership, deforestation, expansion of monocultures, and new forms of accumulation by dispossession (Harvey 2003) or the forced expulsion of peasants from lands.

Critically, this is just one of the contradictions of the Morales administration, whose commitment to a broader extractive, export-oriented agenda for national development is a matter of public record. The social pressure to satisfy the country's immediate economic needs through extractive industries is what Linda Farthing (2009) describes as the "Dilemmas of Development," which continues to destabilize the natural environment and in turn uproot populations. Despite Morales's rhetoric of "sustainable development" or "respecting Mother Earth," the stark realities of extractivism remain etched in nearly every geographical region of Bolivia. Farthing quotes Apolonia Rodriguez, a 20-year veteran of Bolivia's environmental movement, who notes, "[F]or government after government, sustainable development has been nothing more than a slogan ... we are being devastated by uncontrolled forestry, mining and hydrocarbon extraction, and ever expanding soy cultivation." A primary export-oriented plan of development, Urioste (2010), indicates that this has not provided opportunities for small-scale farmers to take advantage of fair organic forms of trade in the larger global market.

I asked Evo Morales in an interview in the Presidential Palace about his broader vision for the country. He replied:

What is my vision for this country? To, little by little, reduce the asymmetries - from family to family, from department to department, from municipality to municipality, and why not, from continent to continent.... What are we talking about? Equality. Justice. Complementarity. I am talking, in other words, about a socialism [un socialismo]. I continue to be convinced that capitalism is the worst enemy of humanity. Why do I say that to you? I, for example, if I want to concentrate capital in my power, or in my family-or 
if I, as president, want my country to be capitalist... I have to invent wars, invade, exploit, humiliate, and turn people into slaves. The life of others is of no interest to me, as long as I have money.

While all of this might appeal to Leftist intellectuals and social movement activists, to what extent does Morales's plan become a merely symbolic socialism, lacking the material and structural reforms necessary to radically alter the historic inequalities and legacies of extractivism in Bolivia? Jeffrey Webber (2010) might refer to this as Morales's co-optation of radical movement politics, a shift from social revolution-which exploded around recovering and reclaiming natural resource wealth in the 1990 s and 2000 s- to a state-based reformism.

While Webber rightly notes that there has been a shift from radical movement politics to reformism, there has also been an interesting and complex identification process with the Morales administration. How, then, can we capture this complex new identification with the state, while working alongside our interlocutors to push the state further left? This is not an easy task for intellectuals and/or activists. While on one hand, movements like MST-Bolivia realize that the kinds of platforms for eliminating the latifundio have not been met, on the other hand, they are not prepared (as they have been in the past) to "tumbarlo este gobierno" [bring down this governing body]. Many activists might find themselves trapped inside this complex new entanglement of hope, identification with the state, and the daily frictions of their ever-more impoverished and difficult lives.

Students from La Universidad Mayor de San Simon in Cochabamba and La Universidad Autonoma Gabriel Rene Moreno in Santa Cruz have posed other kinds of questions: To what extent do movements (that identify with Morales) fail to be revolutionary in a moment of left-leaning reformism? How, and to what extent has Morales pacified these Leftist movements? These questions prove important as we begin to think about the kinds of militant actions of land occupations and the radical respatialization of agrarian production, transferring lands from transnational corporations to community-based and agro-ecologically sustainable agricultural use. In part, as a consequence of the endless horizon of hope associated with state land policies, landless movement activists, directly engaged in battles prior to Morales, are now resigned to a politics of waiting for a reform, which may never take place.

If Morales continues to support land appropriation by the oligarchy for bio-diesel industries - turning food production into possible energy sources-he and his administration will exacerbate social and economic trends his administration and the landless peasant movement originally imagined containing and overcoming through ideas like "food sovereignty" as opposed to food dependency, increasing levels of poverty, and displacement. As Miguel Urioste (2010) exclaims:

It is a perverse consequence of free trade agreements, of the immorality of investors and countries that move between two codes: the tiny foreign aid flows for development on one side (including the MDGs of the UN) and the huge subsidies to the financial sectors which caused the global crisis.... Land grabbing is a disastrous modernization of colonial relations of dependence that will enhance food security for rich and emerging countries at the expense of worsening conditions of poverty and malnutrition in poor countries. (7) 
If movements have now been pacified as a result of a broader campaign of hope for reform, then, where does this leave us in terms of pushing for an alternative agrarian structure? How will movements realign interests and re-create grassroots agendas that challenge this administration, which they view as an ally in their struggles?

The gas protests in December 2010 are, perhaps, the most recent example of pushback against Morales. The Morales government removed a national gas subsidy, causing transport fuel costs to rise more than $80 \%$ overnight, from $\$ 1.97 /$ gallon to $\$ 3.42 /$ gallon, and Bolivian popular movements became vocal and militant. The media called the policy change the "Gasolinazo," or "The Big Gasoline Hit," and the gasolinazo led to an immediate mobilization by the country's social movements. This was the first massive protest in opposition to the Morales administration's policies concerning natural resource pricing and distribution. These protests demanded rapid response on his part, because they threatened to topple his administration. It was on this basis that in a New Year's Eve message to the nation, Morales said that he had listened to the unions and social organizations, and had decided to rescind the decree, winning support from the movements once again. This healthy tension between state policy, no matter its original loyalties, is at best forged out of a push/pull between grassroots, popular interests, and the claims of concentrated wealth, which must be recreated. The greater investiture of hope in the Morales administration by popular indigenous movements has predictably led to policies increasingly driven by global capital and not the will of grassroots organizations.

Critically, however, social movements in Bolivia, in this moment of resource crisis, have the capacity to rebuild, to re-create their politics of the streets, and to reclaim state power. As Bolivia remains teetering on the brink of survival (due to ecological shifts that are radically remapping farming communities and hurting their ability to survive post-privatization of water dilemmas), crisis loom larges in the foreground and background of the political landscape. As Neil Smith once said, "Out of crisis might come great possibility for Revolution...as anger at the economic crisis builds, as old movements remake themselves, and as new movements emerge around (and often combining) issues as diverse as immigrant rights and police brutality, environmental destruction and labor organizing, decimated social services and indigenous rights, a political reconstruction of the left is urgent" (Smith 2009: 57).

The challenge that lies ahead must be, in large part, framed by the following question; how can movements realign their interests, separate their immediate aspirations from state politics, and reconstruct their radical project? As has been suggested, it matters little to a progressive radical project whether a nation-state is left-leaning, center-left, or moderate. In the absence of a sustained progressive movement pressure, states will remain relatively ineffective in resisting or offering alternative policy to transnational agendas.

What is abundantly clear and increasingly cannot be denied by even transnational corporations is that we are in a moment of ecological, environmental, and economical crisis. As people's lives are unraveling-whether due to brutal attacks on economically stable employment, the right to unionize, or widespread ecological crises-which in turn tend to destabilize and uproot whole populations, there is an 
urgent need for a political reconstitution of the Left as social project and political practice. Intellectuals and activists alike must create the appropriate forums to move beyond a "symbolic politics" and to imagine and put into practice radically new structures of equality and redistribution. As Neil Smith has indicated, "one earns one's freedom and life when one takes them every day by storm" (2009: 64). This has always been the history of revolution in Latin America. While the era of multicultural reforms might have brought with it new symbolic revolutions, this will not lead to a restructuring of our economy; this reformation will only happen when workers, aligned with peasants, indigenous peoples, and the global North and South seize their rights "by storm."

\section{References}

Farthing, Linda. 2009. Bolivia's dilemma: development confronts the legacy of extraction. NACLA 42(5): 25-30.

Gill, Lelsey. 1987. Peasants, entrepreneurs, and social change: Frontier development in lowland Bolivia. Boulder: Westview Press.

Gustafson, Bret. 2006. Spectacles of autonomy and crisis: Or, what bulls and beauty queens have to do with regionalism in Eastern Bolivia. Journal of Latin American Anthropology 11(2): 351-379.

Harvey, David. 2003. The new imperialism. Oxford: Oxford University Press.

Kohl, Benjamin. 2003. Restructuring citizenship in Bolivia: El plan de todos. International Journal of Urban and Regional Research 27(2): 337-351.

Smith, Neil. 2009. The revolutionary imperative. Antipode 41(1): 50-65.

Urioste, Miguel. 2010. Land governance in Bolivia. Fundación Tierra. Unpublished Paper.

Webber, Jeffrey. 2010. From rebellion to reform in Bolivia: Class struggle, indigenous liberation, and the politics of Evo Morales. Chicago, IL: Haymarket Books. 